\title{
OS CRUCEIROS DE CAPELA: V. CONCELLO DE RIANXO (I)
}

\author{
Por \\ CLODIO GONZÁLEZ PÉREZ
}

Este é o quinto capítulo que dedicamos ós cruceiros de capela ou de fornela. Nos anteriores publicouse a catalogación dos existentes nos concellos de Rois, Ribeira, Brión e Ames ${ }^{1}$.

Aínda que non adoito dedica-los traballos, este en particular vai na memoria de Castelao, non soamente por ter nado en Rianxo, senón por ser el o primeiro que lle dedicou un pequeno apartado do seu magnífico libro -en tódolos aspectos-As cruces de pedra na Galiza (Buenos Aires, 1950), base de cantos se teñen feito ata agora, entre os que tamén contamos os nosos².

\section{CRUCEIROS DO CONCELLO DE RIANXO}

Segundo o inventario elaborado polo concello ${ }^{3}$, actualmente érguense no seu territorio $\left(58^{\prime} 99 \mathrm{~km}^{2}\right) 101$ obras, contando os cruceiros de capela, os cruceiros de varal e as sinxelas cruces. Polo xeral atópanse ben conser-

\footnotetext{
' C. GONZÁLEZ PÉREZ: «Os cruceiros de capela», Cuadernos de Estudios Gallegos, núms. 103 (1989), 104 (1990), 105 (1992), 107 (1995) e 108 (1996).

${ }^{2}$ Páxs. 175 e 176.

3 Agradezo ó alcalde, Pedro Piñeiro Hermida, e a Fernando R. Lavandeira Suárez, a xentileza de pór á miña disposición este inventario artístico.
}

"CUADERNOS DE ESTUdIOS GALLEGOS", Tomo XLV, Fascículo 110, Santiago 1998. 
vados, pero non faltan algúns mutilados, dos que ás veces non chegou ata os nosos días máis que o baseamento e o esteo. Entre todos eles sobresaen os 87 que contan con algunha representación iconográfica.

A súa distribución por parroquias é a seguinte:

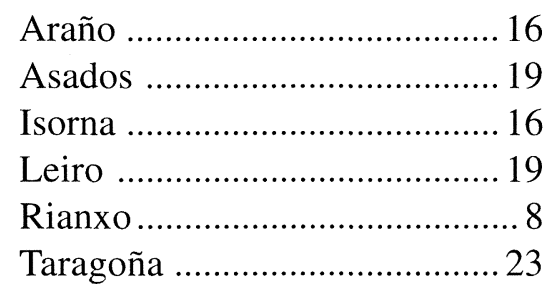

Aténdonos ós datados, é dicir, que contan con inscrición na que figura o ano en que foron labrados, o máis antigo vén ser un do Araño, de 1630, que escolleu Castelao para figurar como ilustración do seu libro (lámina LX), que é contemporáneo dalgúns dos de capela e, posiblemente, do mesmo santeiro. Entre os conxuntos sobresae o calvario de Isorna, e entre os mellor situados, o que fica na praza da igrexa de Rianxo, fronte ó pazo de Martelo (biblioteca pública municipal). (Ilust. I).

Nos últimos anos foron restaurados algúns, pero aínda cómpre proceder a recuperar varios máis mutilados dende xa hai anos, repoñendo as partes que faltan por outras novas, coidando de que concorden co estilo das vellas, como fixo con grande acerto o santeiro Xoán Cabeza (do Porto do Son) co de capela da aldea da Pastoriza (Taragoña), en 1993. A situación máis precaria é a dos que quedan lonxe das casas, que corren o perigo de que os rouben (senón todo, as pezas máis importantes).

\section{CRUCEIROS DE CAPELA DE RIANXO}

Este concello debera inicia-lo noso inventario de cruceiros de capela, non polo número de obras, senón porque foi onde naceu o primeiro investigador que se parou a estudialos, a debuxalos e a procurarlles unha posible orixe. Referímonos, por suposto, a Castelao. En As cruces de Pedra na Galiza (que vai para 50 anos que saíu do prelo) só reproduce dous rianxeiros de varal: un de Asados e outro do Araño, pero en cambio, polo que atinxe ós de capela, dos nove que publica, sete pertencen a este 


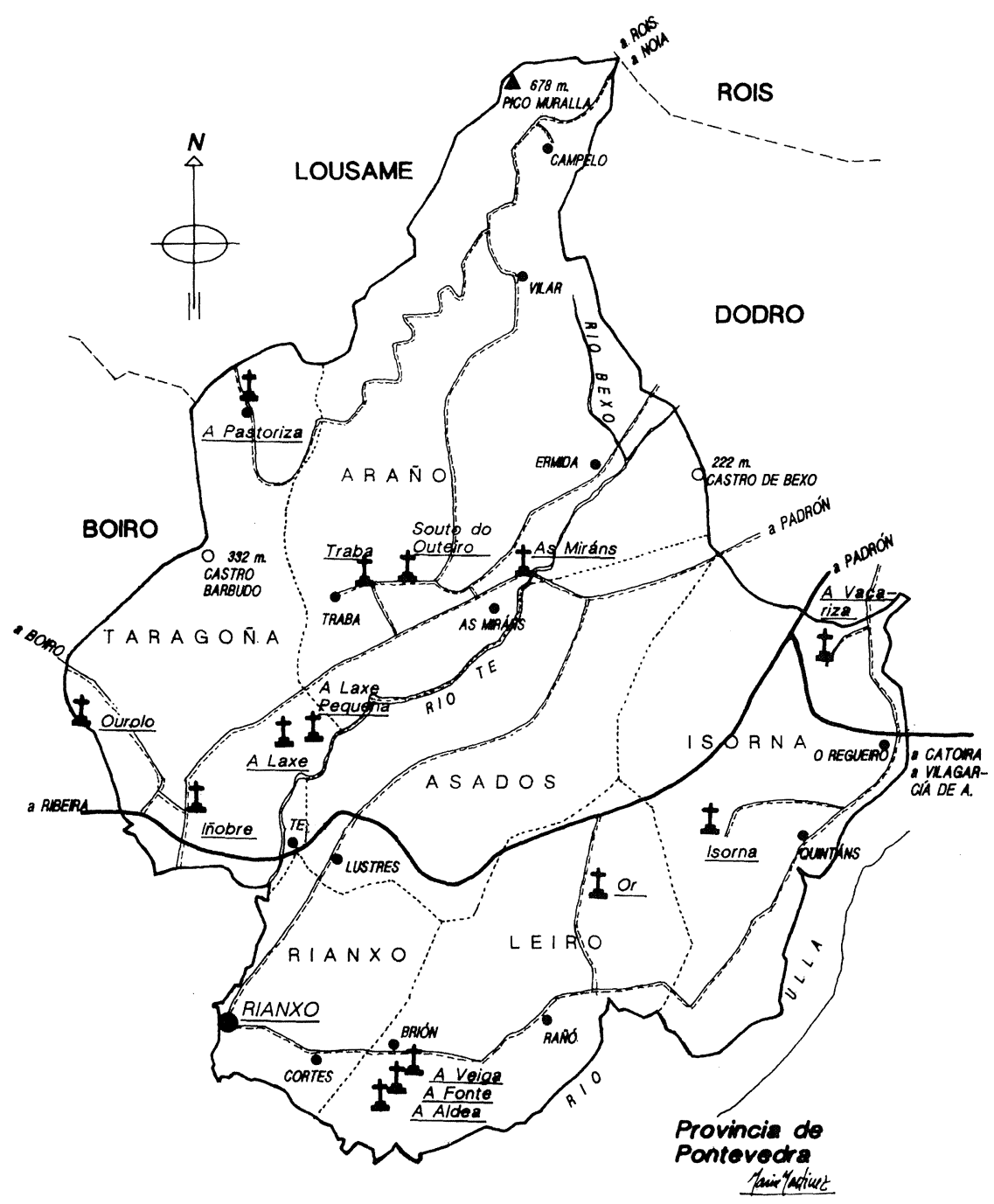

Ilustración I: Concello de Rianxo: Cruceiros de capela. 
concello, entre os que destaca o situado na aldea da Laxe Pequena. Este feito, xunto co que di no texto de que os hai dende Rianxo a Noia seguindo a beira do mar, deu lugar a que dende entón algúns autores (que non se pararon a conta-los existentes nos demais concellos), desen por feito que eran case exclusivos de Rianxo, cando a súa área abrangue a outras terras lindeiras, chegando polo interior ata as portas de Compostela, coma o amosa o magnífico exemplar que se ergue no torreiro da capela de Santo Amaro da Barouta, en Ames ${ }^{4}$.

Outro tema de discusión é o da dedicación á Virxe de Loreto. Sábese que é a advocación de un de fóra deste concello, do que fica diante da capela do lugar de Loreto, parroquia de Noal (Porto do Son). Pero dos demais, por moito que temos preguntado ninguén sabe dar razón. Os de Rianxo, en particular, todos teñen unha imaxe da Virxe, pero é a de Guadalupe (Laxe Pequena), Virxe das Neves (Iñobre, Ourolo), Virxe do Carme (Outeiro), ... ou a «Virxe», sen máis.

O concello de Rianxo conta con seis parroquias, pero en dúas non hai actualmente ningún cruceiro desta clase, que son a capital e a de Asados:

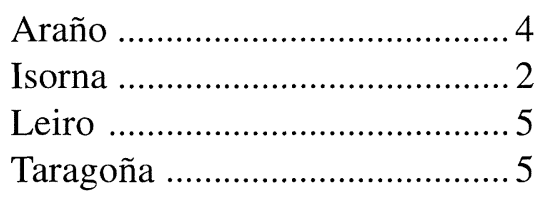

En total son 16, sendo a que máis ten a de Taragoña. De un deles non queda máis que a cruz, que foi asentada sobre o lintel do portalón da casa rectoral de Araño, a poucos metros do hórreo máis longo de Galicia, e outro só se sabe como era por un debuxo de Castelao, pero descoñécese agora onde estaba situado. Por último, anque este non o contamos, está un moderno que mandou labrar unha familia no lugar da Vacariza (Isorna), en 1994.

A situación xeográfica dos existentes indica moi pouco, porque aínda que hai unha freguesía do interior que non ten ningún (Asados), outro tanto sucede coa máis mariñeira de todas, a de Rianxo.

${ }^{4}$ GONZÁLEZ PÉREZ, C.: «Os cruceiros de capela: IV. Concello de Ames», Cuadernos de Estudios Gallegos, XLIII, 1996.

"CUADERNOS DE ESTUDIOS GALLEGOS", Tomo XLV, Fascículo 110, Santiago 1998. 
Malia que nas últimas décadas foi minguando -en xeral- a devoción que polos cruceiros profesaban os nosos devanceiros, posta de manifesto no farol (ou logo bombilla) que noite e día alumaba pendurado da cruz ou mesmo no chan, polo que se refire ós de capela aínda non se perdeu de todo, como o amosa o feito de que a algúns lles poñan cirios, o que indica que hai persoas que seguen tendo fe nos «santiños» que están alí, coma no da Laxe Pequena, principalmente coincidindo coa festa da Nosa Señora de Guadalupe, por se-la imaxe que se venera na capeliña, e no de Ourolo, ámbolos dous na parroquia de Taragoña. Ramos de flores aínda se poden ver en varios: A Laxe, Pastoriza, Traba, etc. Pola contra, outros están totalmente esquecidos, coma o da Veiga (Brión) e a Vacariza (Isorna). Ante a pregunta de por qué seguían poñéndolle flores e velas, unha señora maior que vive de par do da Laxe Pequena, respondeunos:-Xa ofacían os vellos, e nós seguimos facendo o que eles nos mandaron.

No concello de Rianxo, o mesmo que nos lindeiros onde existen cruceiros de capela, había o costume -agora perdido- de que as mulleres trocasen a imaxe da Virxe de posición, orientándoa cara ó rumbo que levaba ou traía no mar o marido, noivo, irmán,... Isto veuse facendo, entre outros, no de Ourolo (Taragoña), pois cando o debuxou Castelao, a Virxe estaba cara a dereita do cruceiro, respectando o artista rianxeiro esta posición. Debeu ser moi corrente sobre todo ata finais do século pasado, pois en 1885 dan fe del os redactores do Cuestionario del Folk-lore gallego ${ }^{5}$.

\section{PARROQUIA DE SANTA BAIA DO ARAÑO}

É a que queda máis lonxe do mar, lindante cos concellos de Dodro, Rois e Lousame. Actualmente existen en total 19 exemplares, entre cruceiros e cruces, dos que tres son de capeliña, situados nas aldeas de Traba, O Outeiro e As Miráns. No tocante á propiedade, só hai un privado, pero en lugar ó que pode acceder calquera persoa.

${ }^{5}$ Madrid, 1885, p. 29.

"CUADERNOS DE ESTUDIOS GALLEGOS", Tomo XLV, Fascículo 110, Santiago 1998. 


\section{CRUCEIRO DO CAMPO DA PONTE}

\section{Situación}

Atópase no lugar das Miráns, logo de pasar un ponte que salva o río Te, no medio dun terreo agora arranxado para área de lecer, coñecido por Campo da Ponte. Ultimamente foi restaurado, polo que o seu estado de conservación é bo. (Ilust. II).

\section{Descrición}

Figura na obra de Castelao, lámina LXXI. Daquela, antes da guerra civil de 1936/39, aínda se conservaba a imaxe da Virxe na capeliña, que logo desaparecería. (Ilust. III).

O baseamento consta de dous chanzos de igual altura, afincándose o fuste no medio do segundo. Este é de sección cadrada pero coas arestas chafranadas, agás nos extremos, tanto inferior como superior. No cabo dos catro rebaixes ten como motivo ornamental unha especie de bola.

O capitel é de catro lados lisos, agás o frontal que, como na maioría destes cruceiros, conta cunha cara de anxiño ou querubín con ás. Sobre el aséntase a capela, formada por tres pedras laterais, máis unha inferior (o capitel) e outra superior (a cuberta). Esta última por debaixo é totalmente plana. Carece de motivos ornamentais, agás os cantos das xambas ou lousas laterais que están rebaixados cara a dentro, coa fin de aumenta-la luminosidade no interior da fornela. Aprécianse restos de pintura, que amosan que en tempos pasados -aínda non moi afastados- estivo policromado, por dentro e por fóra. Como xa queda dito, na fornela había unha imaxe da Virxe que tiña as mans dereitas en actitude de rezar, envolta nun manto con abundantes pregos. Descoñecémo-la data da súa desaparición.

O monumento coróase coa cruz, de sección cadrada coas arestas rebaixadas en perfil cóncavo, agás nos extremos. A figura de Cristo está toda ela apegada a cruz, coa cabeza caída cara á dereita, polo que o limbo circular non lle queda xusto por detrás. Os trazos son bos, en particular a barba crecha con simétricos rizos e o cabelo que lle chega ós ombreiros, distinguíndose claramente sobre el a coroa de espiñas. O pano de pureza anóase á esquerda, como adoita ser tradicional, cunha lazada grande que cae lateralmente chegándolle ata máis abaixo dos xeonllos.

Mide de alto, contando tamén os chanzos, 4’21 m. 


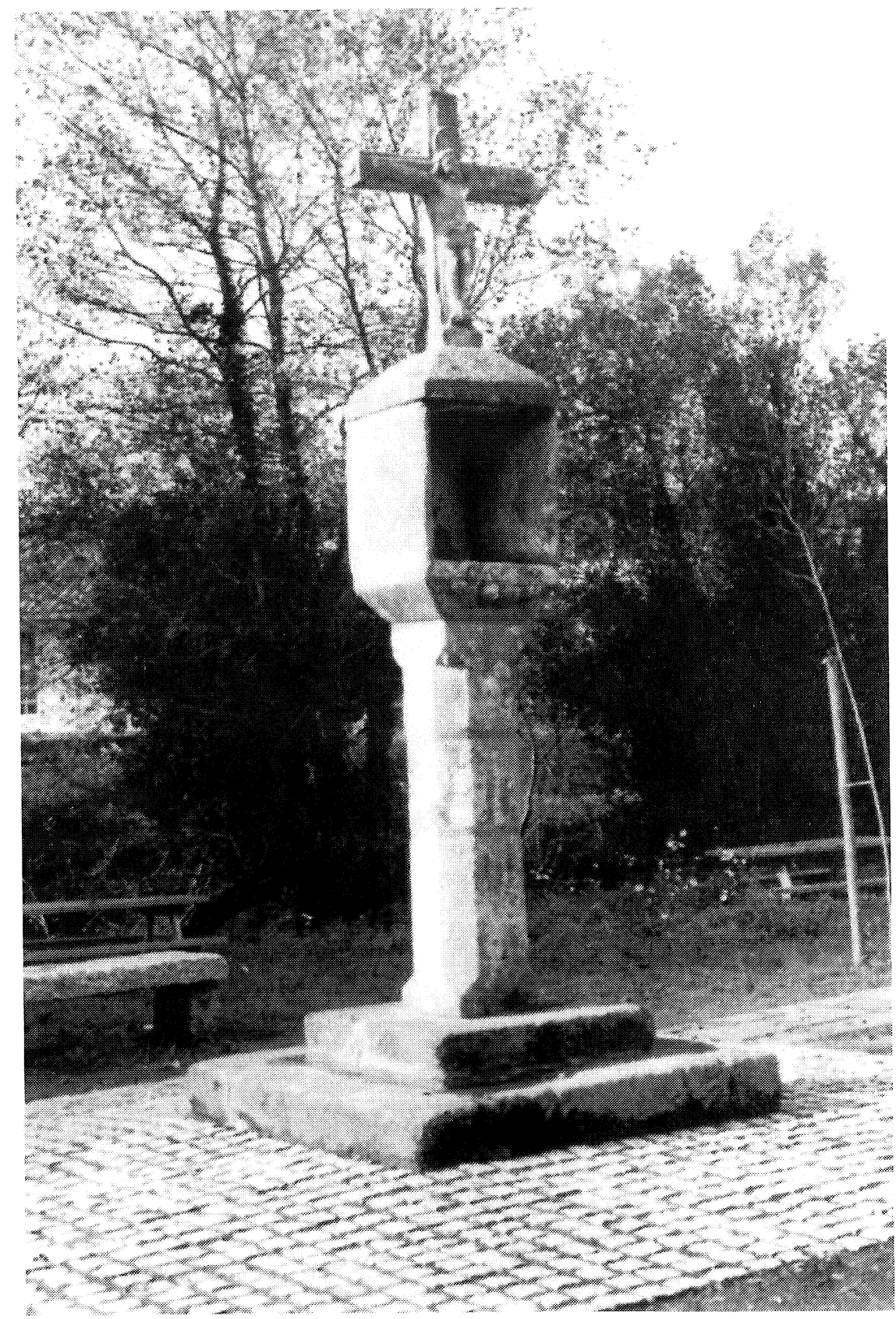

Ilustración II: Cruceiro do Campo da Ponte (As Miráns). 


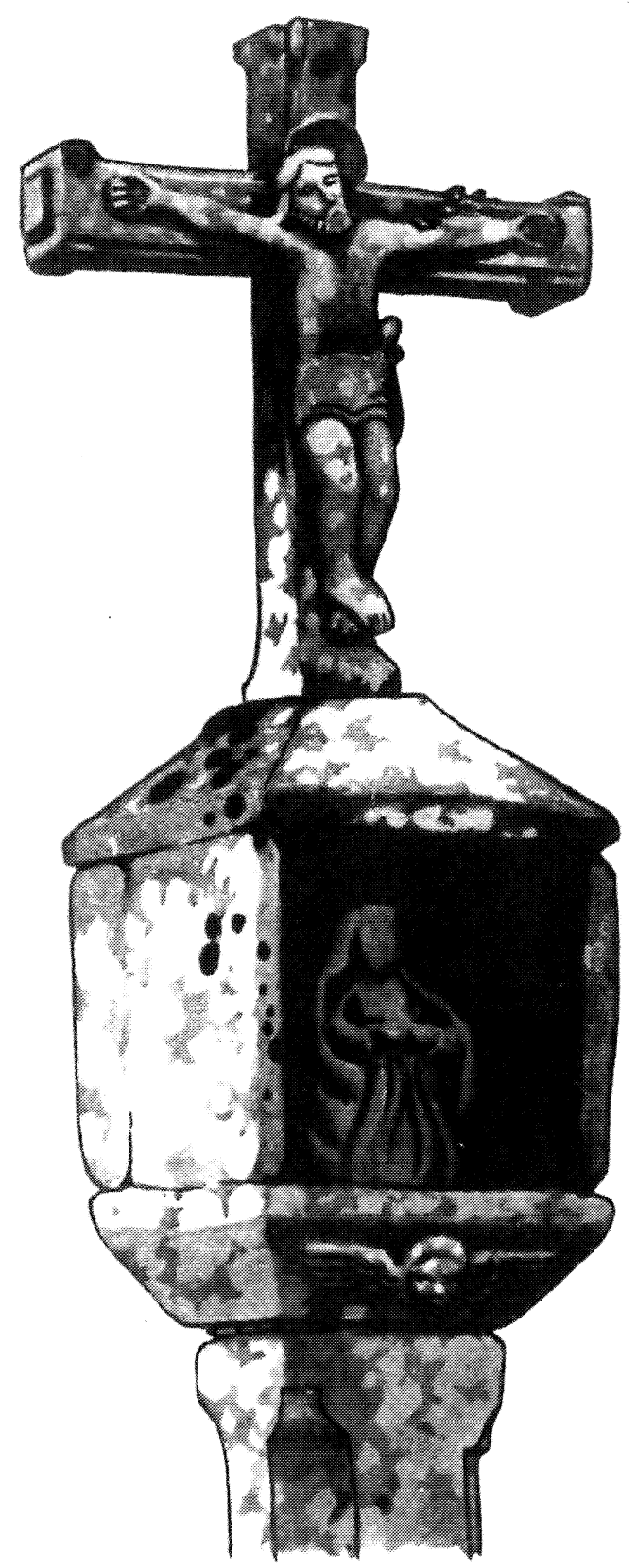

Ilustración III: Cruceiro das Miráns, debuxo de Castelao. 


\section{Historia}

Carece de inscrición. Tendo en conta algúns trazos estilísticos, coidamos que pode datar de finais do século XVI ou comezos do XVII, caracterizándose a parte escultórica (a figura de Cristo, que é a única que se conserva) por certo arcaismo que lembra obras anteriores. Do mesmo santeiro ou discípulos son, entre outros, o de Ourolo (Taragoña), o da Pedrafurada (Caamaño, Porto do Son), o do Cubeliño (Boiro), e a cruz que está sobre o lintel da casa rectoral do Araño que procede dun desaparecido. Todos eles carecen de data.

É de propiedade pública.

\section{Tradicións}

Aínda que agora non sexan máis que camiños abandonados, cubertos de vexetación, a encrucillada onde queda o cruceiro, logo de pasa-lo río $\mathrm{Te}$, foi antano moi transitada, polo que non faltaban devotos que lle mantivesen sempre o farol aceso.

A soidade do lugar faino moi axeitado para escenario de lendas e historias de aparecidos, sobre todo nas escuras noites de invernía.

\section{CRUCEIRO DA CASA DO CREGO OU RECTORAL}

\section{Situación}

Actualmente a única peza que queda é a cruz, que foi asentada sobre o lintel (de cemento) do portalón de entrada á casa rectoral. Ninguén soubo dar razón do lugar da parroquia onde estivo o cruceiro, do que se deduce que xa hai moitos anos que desapareceu. (Ilust. IV).

\section{Descrición}

Como queda dito, agora o único que se conserva é a cruz, pero non hai dúbida que procede dun cruceiro de capela. Trátase dunha obra de boa factura, de sección cadrada coas arestas chafranadas con perfil cóncavo, con un pequeno motivo ornamental ovalado nos cabos dos brazos, semellante a unha cabeza de cravo.

A figura de Cristo é de escaso vulto, con todo o corpo apegado a cruz, polo que os trazos fisionómicos distínguense pouco, agás as costelas. A parte máis interesante é a cabeza, ladeada cara a dereita, con longo cabelo 


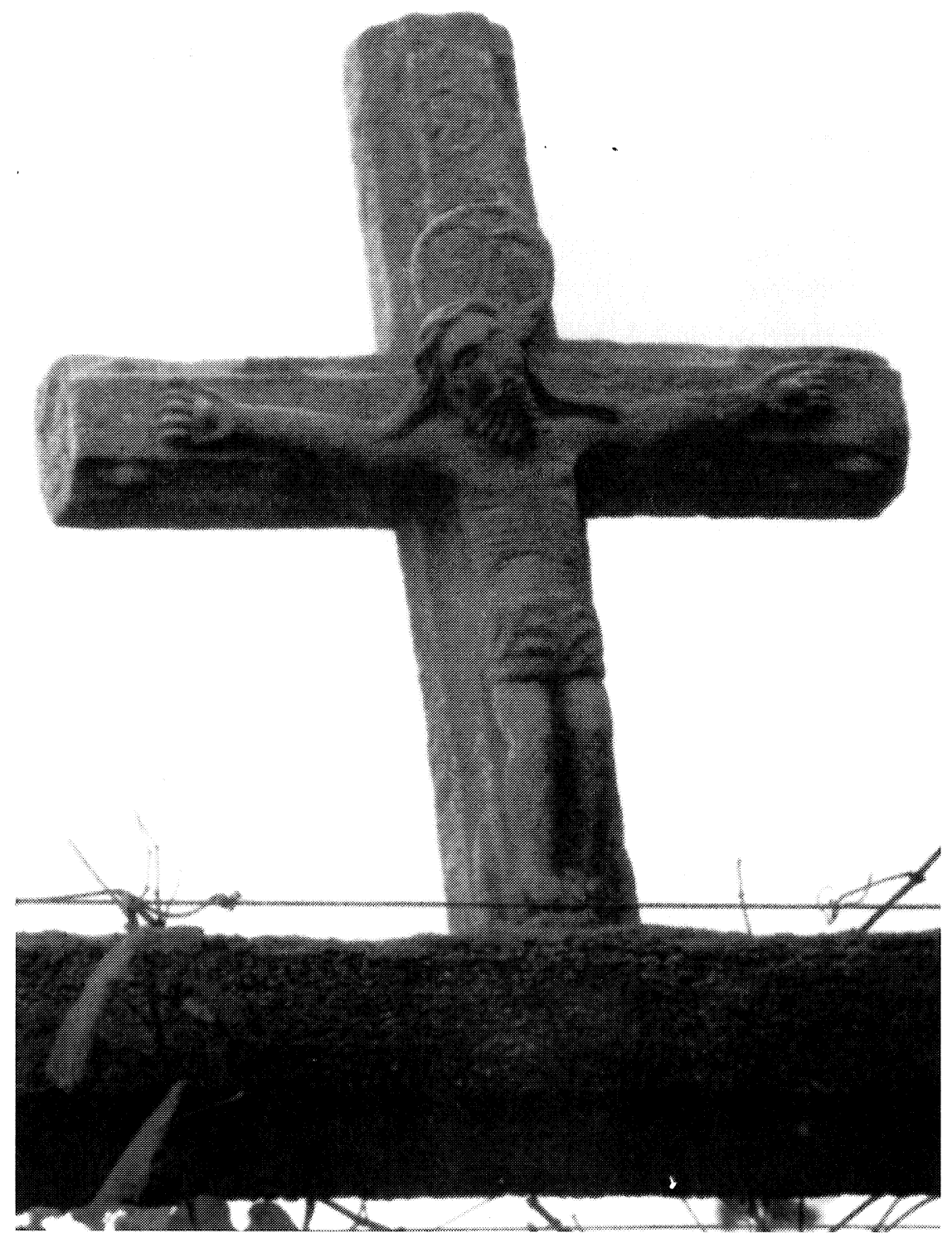

Ilustración IV: Cruz da casa do crego ou rectoral. 
que lle cae simetricamente nos ombreiros chegándolle á metade dos brazos, barba crecha con abundantes e tamén simétricos rizos, e o bigote ben marcado. Destacan polo seu grandor as cabezas dos cravos e, en particular, as das mans, cos dedos postos do mesmo xeito nas dúas. Por enriba da cabeza de Cristo, pero centrado sobre a cruz, está o nimbo, de considerable tamaño, no que se aprecian inscritos dous círculos. O pano de pureza é pequeno, moi cinxido ó corpo e sen nó, rematando á dereita metido o cabo na cintura.

\section{Historia}

Estamos ante unha obra posiblemente do último cuarto do século XVI ou primeiros anos do XVII, do mesmo santeiro, discípulo ou obradoiro, que o anterior, é dicir, o do Campo da Ponte da aldea das Miráns.

\section{CRUCEIRO DO SOUTO}

\section{Situación}

Nunha encrucillada en «T», a curta distancia da aldea do Outeiro. A denominación do lugar onde se atopa, indica que en tempos pasados debeu haber varios castiñeiros. (Ilust. V).

\section{Descrición}

O baseamento consta de dous chanzos, facendo o segundo de base do fuste, monolítico e totalmente liso, de sección cadrada nos extremos e o resto cos cantos rebaixados.

O capitel é pouco voluminoso, de catro lados, adornado con moldura corrida todo arredor. Sobre el aséntanse as tres pedras que forman os laterais da fornela, das que as xambas teñen no fronte como ornamento unha estría ou rebaixe central, case de arriba a abaixo. A pedra da cuberta é totalmente lisa por dentro, pero polo exterior é a catro «augas» que ascenden curvilíneas cóncavas, ata rematar formando un podio, no medio do que se afinca a cruz. Dentro acóllese unha imaxe da Virxe do Carme, co Meniño Xesús na man esquerda que se agarra a Nai, mentres que na dereita tivo un escapulario de metal, agora perdido. Viste a indumentaria propia da orde. Como peaña ten unha nube con unha cabeza de anxo na fronte (Ilust. VI). 


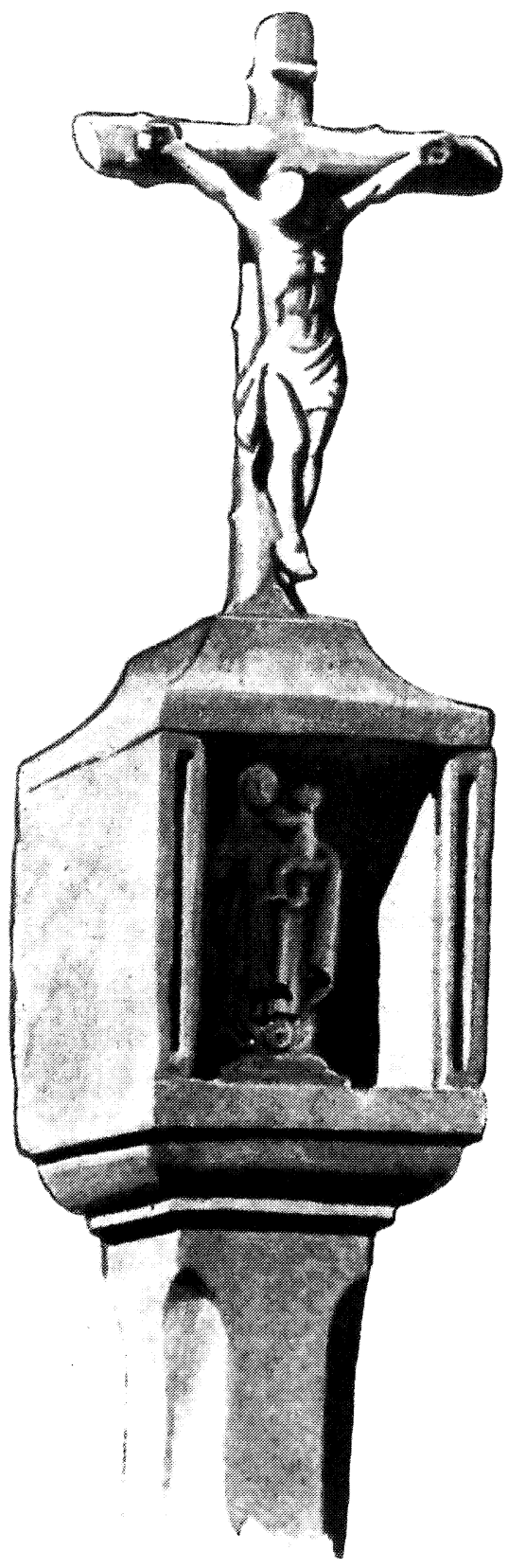

Ilustración V. Cruceiro do Souto (O Outeiro). Debuxo de Castelao. 


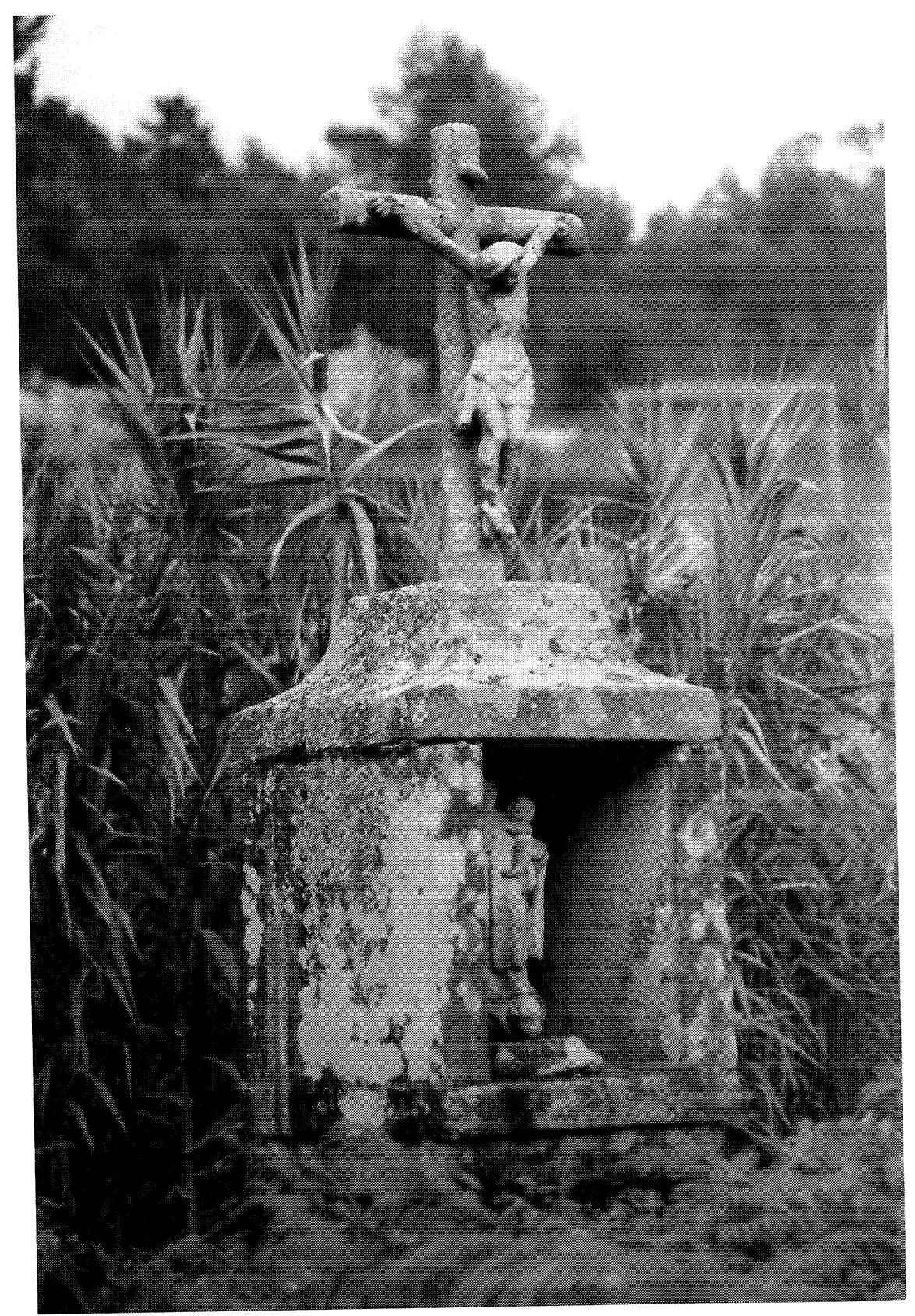

Ilustración VI. Cruceiro do Souto. Capela. 
A cruz é única no seu estilo, xa que nin neste concello nin tampouco nos lindeiros sabemos doutra semellante, pois mentres que todas elas adoitan ser pezas robustas e grosas, a deste cruceiro caracterízase polo contrario, por tratarse dunha labra moi fina, imitando máis as obras dos escultores de madeira que as dos santeiros de pedra: de sección circular con varios nós semellando pao, pouco voluminosa e cos extremos dos brazos rematados en sesgo. A imaxe de Cristo está case exenta, o que lle confire un aspecto moi fráxil pola delicadeza da talla. $\mathrm{O}$ crucificado xa está morto, co corpo caído sen gonzos, e coa cabeza botada para a dereita, sobre a que se distingue claramente a coroa de espiñas. Ten a anatomía moi ben acadada, en particular a pectoral e a ventral. O amplo e frouxo pano de pureza anóase á dereita, cunha lazada grande que lle cae lateralmente. Remata co pergameo do INRI sobre o esteo da cruz.

O conxunto mide sobre $4^{\prime} 30 \mathrm{~m}$.

\section{Historia}

Este cruceiro é o máis moderno do concello, non xa porque na fornela estea unha imaxe da Virxe do Carme, que puidera ser posterior (aínda que neste caso coidamos que se debe ó mesmo santeiro), senón polos trazos estilísticos de toda a obra. Castelao, que o reproduce na lámina LXXIV, non dá ningunha data, do que se deduce que xa cando el o debuxou carecía de inscrición. Do mesmo autor ou taller non hai dúbida que é un de varal situado na freguesía de Asados, que tamén reproduce o artista rianxeiro e que, igual ó do Souto, non ten data. Tamén coidamos que pertenza este descoñecido santeiro o Cristo que hai nunha fornela na parede dunha casa no lugar de Ourolo (Taragoña).

Non é doado procurarlle unha data, pero atendendo a certos trazos estilísticos, coidamos que puido ser labrado no século XIX, en particular na segunda metade ${ }^{6}$.

${ }^{6}$ Os primeiros cruceiros coa Virxe baixo esta advocación datan de mediados do século XVIII, e poideran ser: un da parroquia de Cereixo (A Estrada) e outro da de Cornazo (Vilagarcía de Arousa), como consta no libro de F. COLMENERO: El Carmelo ilustrado, con favores de la Reyna de los Ángeles, con indulgencias, y privilegios, con Tropheos y esclaricidas virtudes de sus Hijos..., Valladolid, 1754, p. 364. Sobre a difusión desta advocación mariana en Galicia, C. GONZÁLEZ PÉREZ: «Devocións mariñeiras: Do Corpo Santo á Virxe do Carme» (no prelo).

"CUADERNOS DE ESTUdIOS GALLEGOS", Tomo XLV, Fascículo 110, Santiago 1998. 
Tradicións

Érguese nunha encrucillada do antigo camiño sacramental, agora convertido en estrada, que vai cara a igrexa parroquial e cemiterio, polo que foi durante séculos parada obrigada ó leva-los defuntos.

O que estea baixo a advocación da Virxe do Carme, caso único dos deste concello, fainos pensar que a persoa que pagou a súa labra era ou fora mariñeiro, que o mandaría construír co gallo dunha promesa feita durante un temporal ou en agradecemento por se ter salvado dun naufraxio.

\section{CRUCEIRO DE TRABA}

\section{Situación}

No medio da aldea de Traba, nun altiño sobre unha encrucillada do camiño sacramental que se dirixe a igrexa parroquial. (Ilust. VII).

\section{Descrición}

Aséntase sobre unha rocha natural, que lle fai de alicerces. O baseamento consta de dous chanzos, un grande e o outro moito máis pequeno e alto; este último coas arestas rebaixadas, do que sae o fuste, monolítico e pouco voluminoso, de sección cadrada cos cantos chafranados, cunha punta de diamante no medio de cada un dos catro extremos superiores.

O capitel, de catro lados, con moldura corrida agás no frontal que ten unha cabeza de querubín con ás. A capela é un exemplar único, pois non coñecemos polo de agora ningún exemplar semellante, que estea aberta por diante e tamén por detrás para expoñer outra imaxe. A fronte representa unha fornela dun retablo, con arco escarzano, adornado tanto el como as xambas cunha especie de cordón ou corda en espiral. O teito semella unha bóveda de crucería, cos seus correspondentes nervios e clave central. A abertura contraria é moito máis pequena e sinxela, totalmente lisa con arco de medio punto. Tamén é único o «tellado», que ten en cada ángulo un abultamento redondeado a xeito de pináculo. É un dos poucos que ten varias grapas de ferro polo exterior para soste-las pedras da capela, o que denota que non están ben encaixadas. (Ilust. VIII).

Dentro acóllense tres imaxes, dúas por diante, e unha pola parte de atrás. As primeiras son: San Antonio de Padua, co Neno Xesús sobre a man esquerda e unha flor (azucena) na dereita. Aínda que os trazos son de 


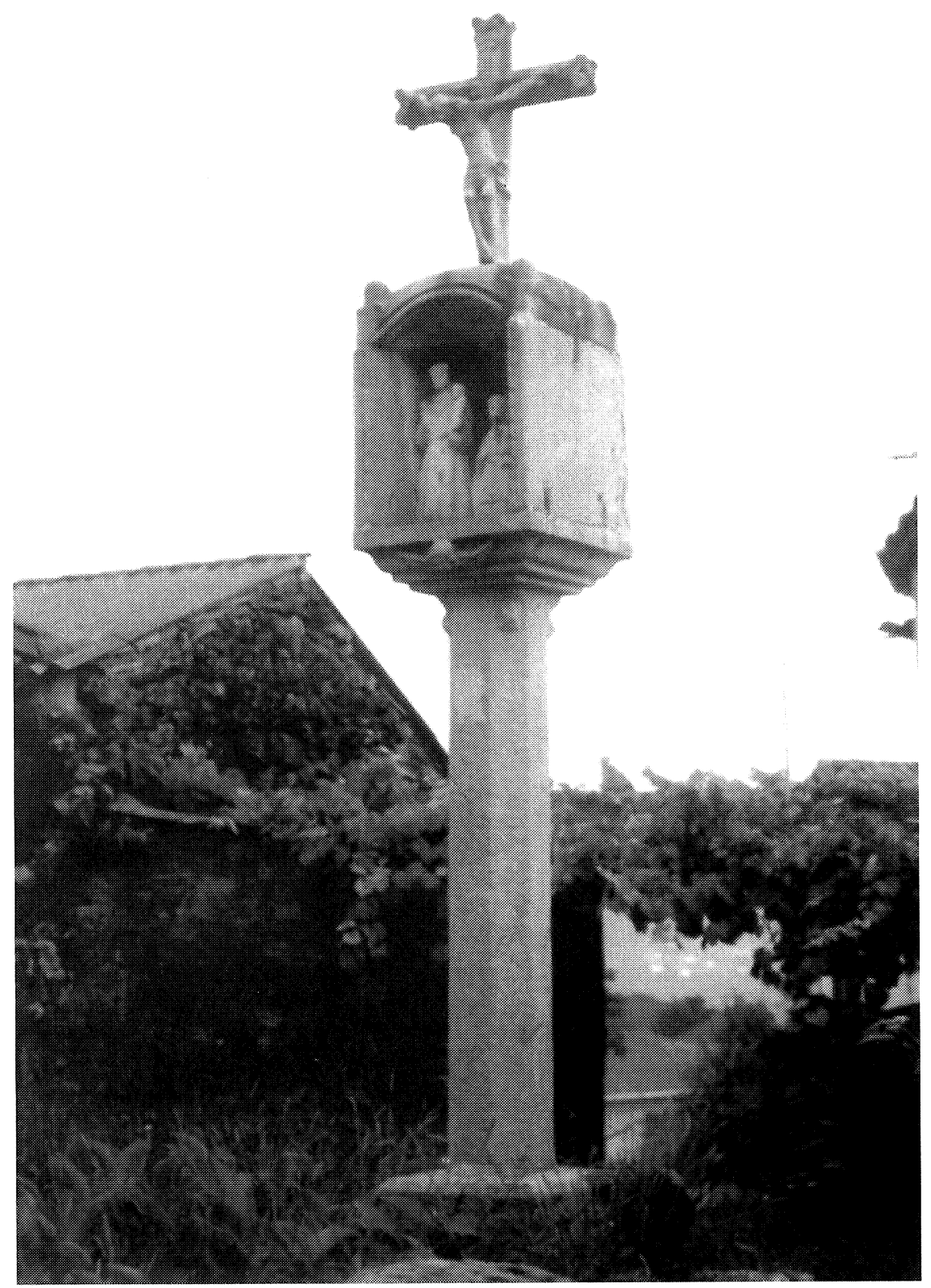

Ilustración VII: Cruceiro de Traba. 


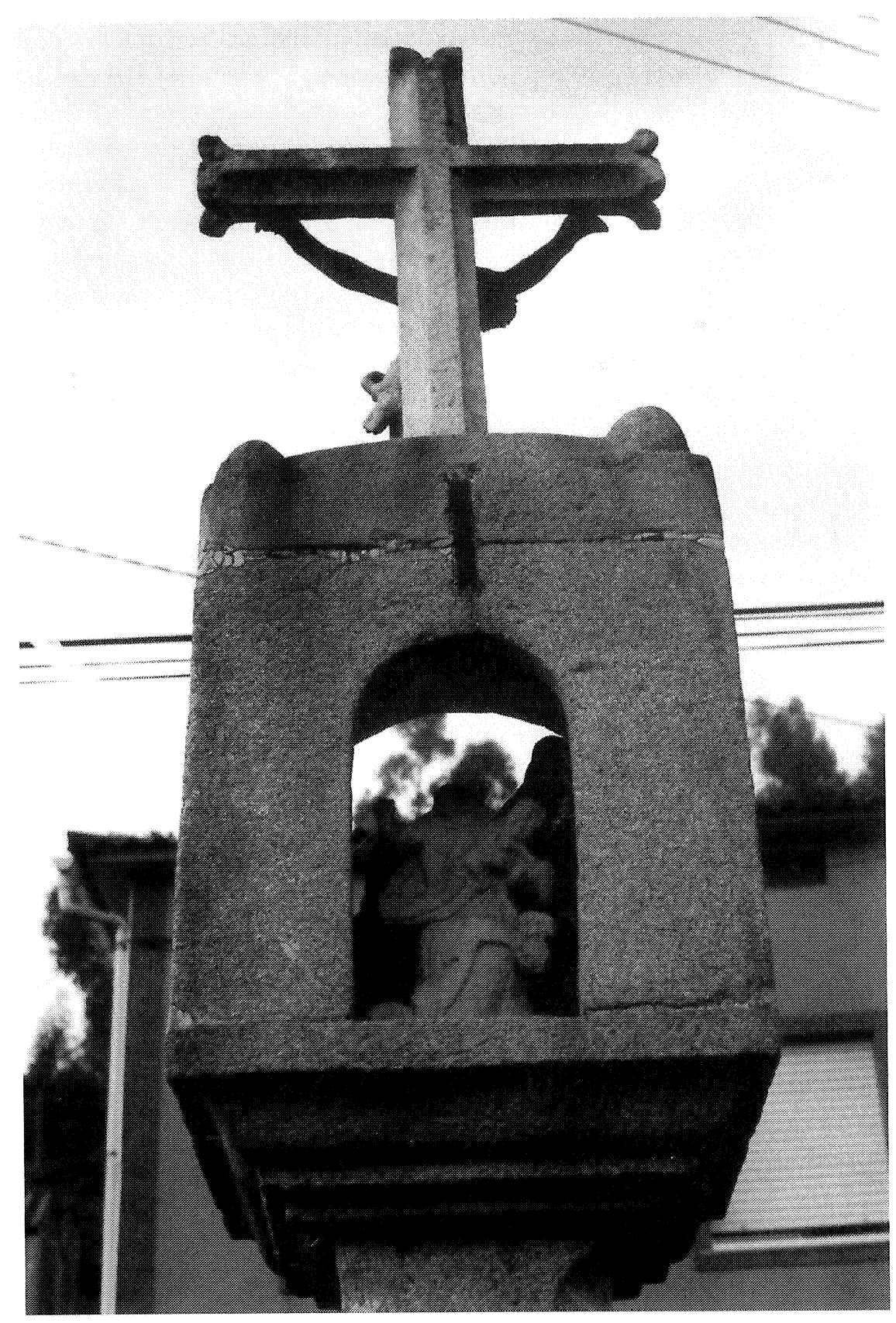

Ilustración VIII: Cruceiro de Traba, posterior da capela. 
escasa calidade, o santeiro soubo representar bastante ben o saial dos franciscanos. A outra imaxe é moito máis tosca, pois carece dos elementais trazos fisionómicos, que representa á Virxe con «algo» que non se identifica na man esquerda, e a dereita apoiada a altura da cintura, e co manto simetricamente caído por detrás que chega ata o chan (Ilust. IX). Por último está a que queda na parte traseira: é unha representación da Virxe do Socorro, actualmente moi mutilada, pois carece de cabeza e tamén perdeu parte da man dereita, así como o pao ou espada que debía ter nela, co que lle dá ó demo que se atopa ós seus pés, representado por un enorme ofidio, defendendo unha alma que está á esquerda, por debaixo do Neno Xesús, da que non queda máis que a cabeza. Esta imaxe, relativamente corrente nos cruceiros de varal (polo de agora esta é a única que coñecemos nun de capela), ten a súa orixe na Virxe do Socorro que se venera no mosteiro compostelán de San Martiño Pinario, que data do ano $1668^{7}$. (Ilust. X).

O conxunto remata coa cruz. Trátase dunha obra moderna de fina labra, posterior ó resto do cruceiro, da que pende a imaxe de Cristo case exenta, agás os tres puntos dos cravos e por detrás do pano de pureza. É de sección octogonal agás nos extremos, que rematan cunha flor de catro pétalos co botón central. O Crucificado derréase cara á dereita, coa anatomía ben acadada e, sobre todo, os pregos do pano de pureza con ampla lazada á esquerda. Por enriba da cabeza campa a cartela do INRI.

O mesmo que a case totalidade dos nosos cruceiros, este tamén estivo policromado, quedándolle restos aínda dentro da capeliña.

En total mide 3'90 metros.

\section{Historia}

Nun dos laterais exteriores da fornela ou capela aprécianse restos de inscrición, pero moi borrosa, na que coidamos non haxa ningunha data. Debido a que se trata dunha obra que, nalgúns aspectos, é única ou moi rara (como o estar a capela aberta tamén por detrás), e que tamén debeu sufrir varios arranxos dende que se ergueu, non é doado procurarlle unha data de fiar. Con moitas reservas coidamos que pode ser da segunda metade do século XVII ou aínda algo posterior.

${ }^{7}$ Cfr. GONZÁLEZ GARCÍA, M.Ạ.: «Datos para la historia de Nuestra Señora del Socorro de Santiago de Compostela», Boletín del Seminario Fontán-Sarmiento, VI VII-VIII, 16-22, 1980.

"CUADERNOS DE ESTUDIOS GALLEGOS", Tomo XLV, Fascículo 110, Santiago 1998. 


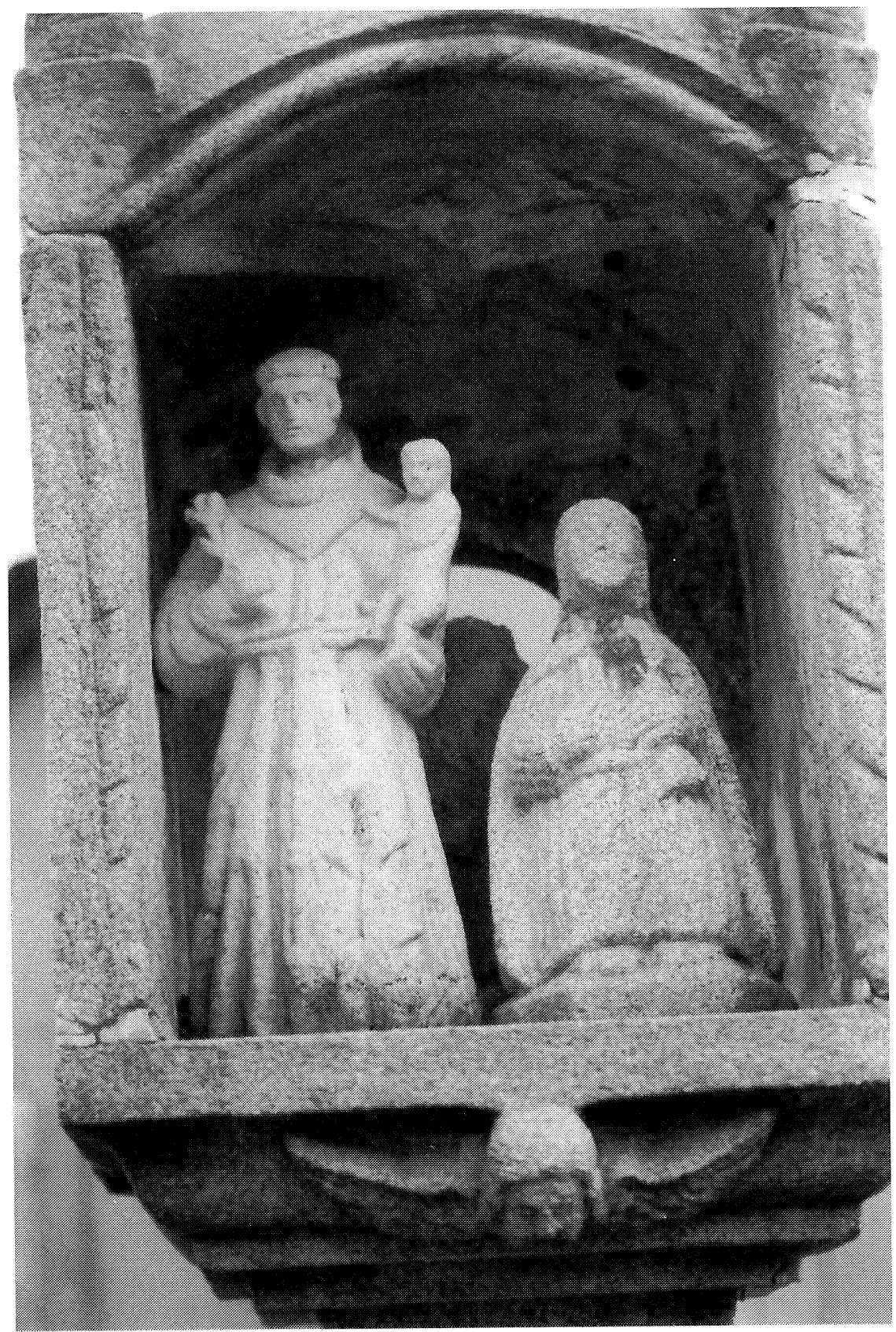

Ilustración IX.: Cruceiro de Traba: Santo Antonio e a Virxe. 


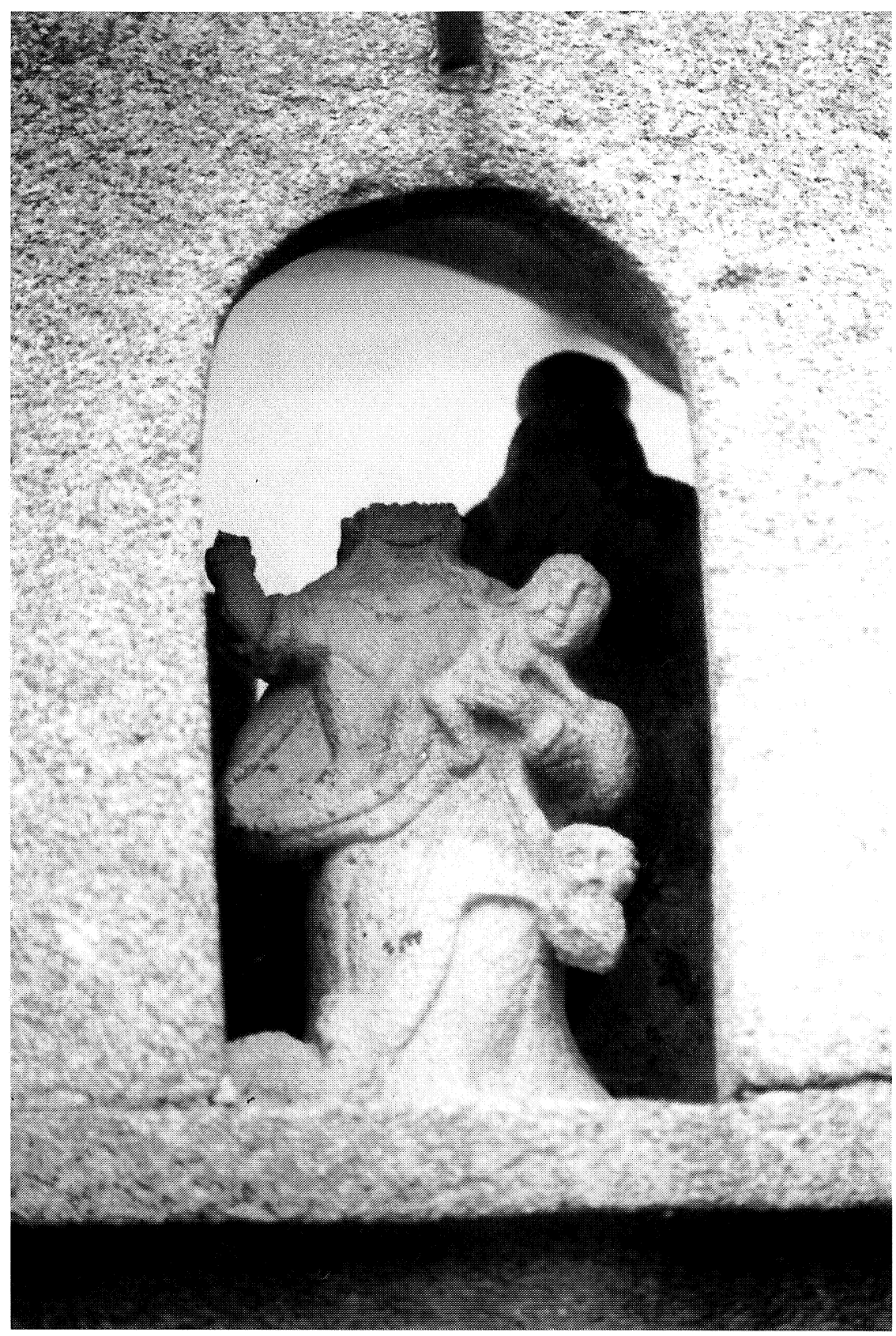

Ilustración X. Cruceiro de Traba: a Virxe do Socorro. 
Segundo o inventario elaborado polo concello, é de propiedade pública.

\section{Tradicións}

Como queda dito, este cruceiro érguese nunha encrucillada do vello camiño sacramental e outros dous, polo que diante del foi parada obrigatoria para os defuntos. As persoas maiores seguen manifestando moita devoción por el, en particular por Santo Antonio de Padua, avogoso de atopa-las cousas ou animais que se perden, así como tamén das mozas solteiras para procurar noivo. Aínda que agora xa se esqueceu o costume, antes diante del alumaba noite e día un farol de aceite que mantiñan os devotos, pero actualmente só lle poñen de cando en vez algún ramo de flores.

\section{PARROQUIA DE SANTA MARÍA DE ISORNA}

Entre cruces, cruceiros de varal e cruceiros de capela, existen 16 obras, de moi desigual valor arquitectónico, pois mentres algunhas non son máis que sinxelas cruces lisas, outras sobresaen polo seu interese artístico, entre as que se achan os dous cruceiros de capela. Como conxunto cómpre sinala-lo calvario, formado por un cruceiro e dúas cruces laterais.

Nos últimos anos púxose de moda poñer un no xardín a carón da casa, non máis que como motivo decorativo. Todos adoitan ser de varal, agás un que mandou labrar unha familia do lugar da Vacariza desta parroquia en 1994, co gallo de que o patrucio da casa, Xesús Miguéns Figueira cumpría cen anos (8-XII-1894 / 1994). A obra, aínda que bonita, semella en pouco ás antigas, por ser máis baixa e estar moito máis traballada, tela cruz pequena, etc. A imaxe da fornela é antiga, e representa a Virxe das Angustias con Xesucristo morto no colo. Foi labrado por un santeiro da zona.

"CUADERNOS DE ESTUDIOS GALLEGOS", Tomo XLV, Fascículo 110, Santiago 1998. 


\section{CRUCEIRO DOS FERREIRO}

\section{Situación}

No medio da aldea de Isorna, nunha encrucillada que antes foi de camiños carreteiros transformados nas últimas décadas en estradas. (Ilust. $\mathrm{XI})$.

\section{Descrición}

O baseamento consta de tres chanzos, aínda que o do fondo agora atópase tapado en parte por subi-lo chan ó asfaltar arredor. O fuste é monolítico de dous metros de altura, de sección cadrada no comezo e logo no remate, sendo o demais octogonal. Posúe un motivo ornamental no comezo e no remate de cada aresta chafranada: nos catro inferiores parecen bolas (ou quizais cabezas moi erosionadas), mentres que dúas das de arriba son cabezas moi desfiguradas, pero aínda se aprecia claramente a súa feitura.

Nun dos rebaixes do fuste ten tallada en baixorrelevo unha figura, moi erosionada e de escasísimo bulto, da que case non se chegan a distinguilos trazos. Con un santo tamén esculpido nun dos chanfráns da columna, pero de moito máis relevo, había un na parroquia de Leiro, que só se coñece por un debuxo de Castelao. Neste caso tratábase do apóstolo Santiago, e tanto a calidade da escultura como a conservación, eran moito mellores que neste de Isorna ${ }^{8}$.

O capitel ou base da capela enféitase con molduras lisas, agás no fronte que -como é case xeral en todos estes cruceiros- ten unha cara de querubín con ás. A fornela é moi interesante, pois o fronte das lousas que corresponden ás xambas e da que fai de tellado, teñen a aresta interior rebaixada e nela sobresaen varias bolas (catro en cada un dos laterais, e cinco arriba). Dentro acóllense tres santiños, dous diante e un acochado detrás deles. Os primeiros son: San Xoán Bautista, coas pernas espidas e cuberto cunha especie de capa ou pelica que lle cae por detrás ata o chan. Na man esquerda terma dun libro ou algo semellante, sobre o que hai un bulto que -coidamos- representa un año. A man dereita tena a altura do peito. A outra imaxe é moito máis pequena, e representa a Virxe coas

${ }^{8}$ As cruces de pedra na Galiza, 1950, lámina LXXIV.

"CUADERNOS DE ESTUDIOS GALLEGOS", Tomo XLV, Fascículo 110, Santiago 1998. 


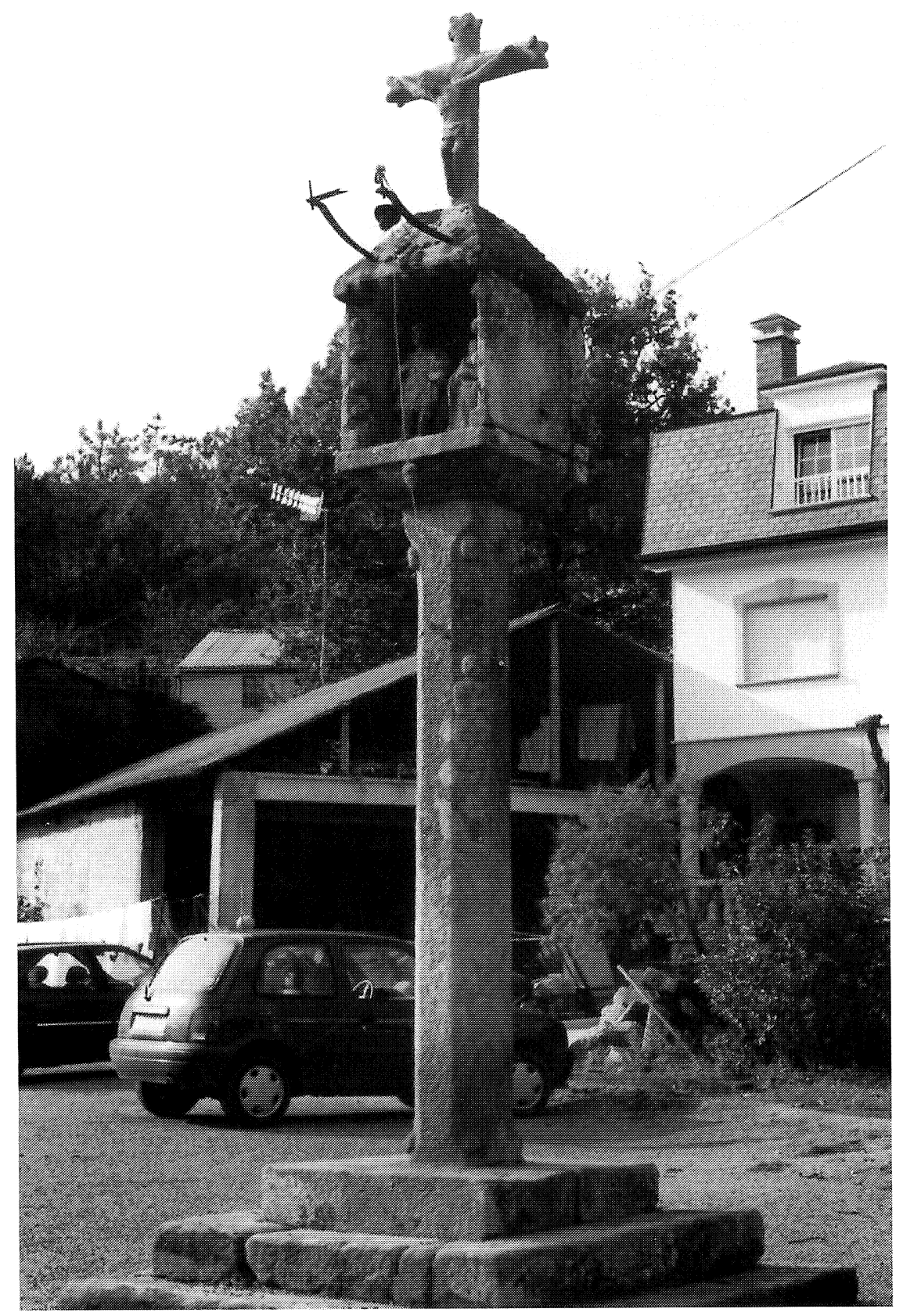

Ilustración XI. Cruceiro dos Ferreiro (Isorna). 
mans dereitas sobre o seo, envolta nun amplo manto. Trátase dunha obra moi sinxela, de escasísima calidade artística, non se lle apreciando nin sequera os trazos máis elementais da cara. Por detrás, case non visible dende abaixo, hai outra pequena imaxe, de difícil identificación. (Ilust. XII).

No cumio do empinado teito piramidal aséntase a cruz, de sección octogonal, agás nos tres cabos en que os rebaixes semellan unha flor de catro pétalos co botón no medio. Cristo ten a cabeza moi ladeada, case tocando con ela o brazo dereito, sobre o que lle cae o cabelo. No lado dereito do peito, por debaixo das costelas, apréciase a ferida que lle produciron ó espetarlle a lanza. Malia a cativa consistencia da pedra, aínda se lle notan os trazos máis sobresaíntes da cara, así como do corpo en xeral. $O$ pano de pureza anóase á esquerda. $O$ conxunto remata coa apergamiñada cartela do INRI.

Estivo pintado, tanto por dentro da fornela, coma no exterior, apreciándose aínda restos de policromía.

Mide, contando tamén o baseamento, 4'70 m.

\section{Historia}

O feito de que sega pertencendo a unha familia da aldea, a dos Ferreiro, é claro indicio de que debeu ser un devanceiro desta casa quen pagou a súa labra. Actualmente carece de inscrición, pero pode datarse na primeira metade do século XVII, cara a 1636, que é o ano que figura no fuste do da aldea da Pastoriza (Taragoña), co que garda certas semellanzas estilísticas, así como tamén con dous do lugar de Brión (Leiro), o da Aldea e o da Fonte, que deben ser do mesmo santeiro ou taller, anque en particular para este último Castelao dá a data de 1667, pero descoñecemos onde se informou, agás que daquela tivera inscrición, da que agora non queda rastro 9 .

Do mesmo artista ou seguidores debe ser, entre algúns máis, o do lugar da Agra de Arriba, no lindeiro concello de Boiro, que tamén carece de data.

Segundo o inventario artístico elaborado polo concello, este cruceiro é de propiedade privada.

\footnotetext{
${ }^{9}$ CASTELAO: Obr. cit., lámina LXXIV.
} 


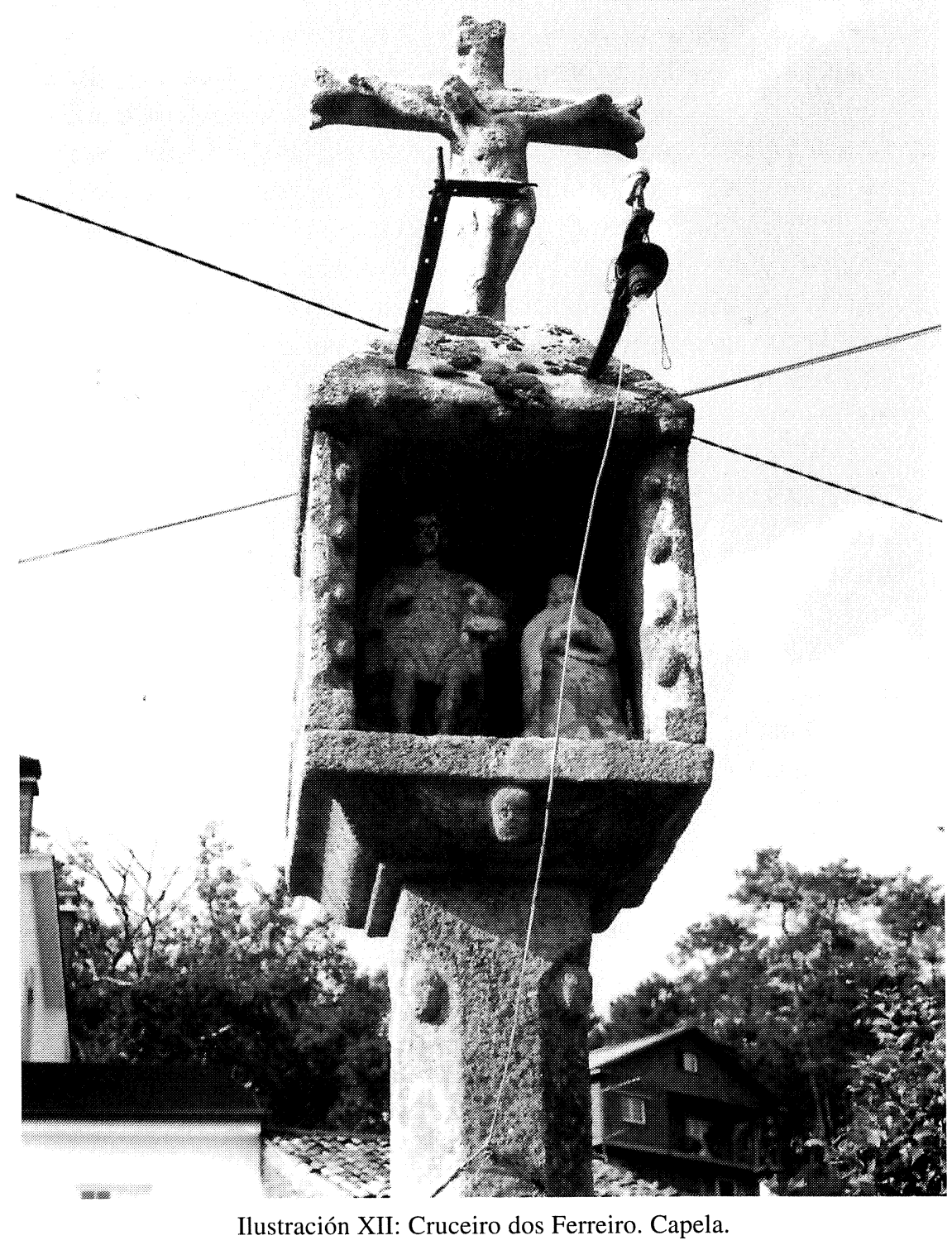

(c) Consejo Superior de Investigaciones Científicas Licencia Creative Commons 3.0 España (by-nc) 


\section{Tradicións}

Érguese nunha antiga encrucillada de varios camiños transformados nas últimas décadas en estradas locais asfaltadas, entre os que estaba o principal da parroquia, que seguían as comitivas fúnebres.

Os veciños mantiveron a tradición durante séculos de que un farol sempre estivese aceso diante da capela. A súa insignificante luz era a única claridade que había no medio da encrucillada. Coa chegada da electricidade foi trocado por unha bombilla, que para sostela diante da capela non tiveron outra ocurrencia que espetar dous ferros na cuberta, afeando o conxunto. Coa perda de devoción que cada vez é máis manifesta, en particular entre a xente nova, a luz do cruceiro quedou abandonada. Urxe retirar canto antes estes ferros, que rematarán por fende-la pedra, ademais de deixarlle para sempre as marcas de ferruxe. A bombilla pode ser substituída por un artístico farol ou mesmo por unha luz que ilume o cruceiro de noite, pero situada de xeito que non afee o conxunto.

\section{CRUCEIRO VELLO}

\section{Situación}

Queda na ribeira do río Ulla, a uns douscentos metros da aldea da Vacariza, sobre unha encrucillada do camiño vello que vai deica a igrexa parroquial de Isorna, e logo a Rianxo, convertido actualmente nunha fonda e abandonada corredoira entre árbores, inundada pola auga sobre todo no inverno. (Ilust. XIII).

\section{Descrición}

O baseamento non é visible agora, polo que se descoñece o número de chanzos, se é que os ten, pois poidera darse o caso que estivese afincado sobre unha rocha.

O fuste é tradicional na súa forma, cadrado coas arestas rebaixadas, agás nos cabos, formado por unha soa pedra totalmente lisa. Tradicional tamén é o capitel de catro lados, tres deles lisos e o frontal con unha cabeza de anxiño con ás. As xambas da fornela teñen as arestas interiores das lousas chafranadas, para aumenta-la claridade dentro. No interior áchase unha imaxe da Virxe da que case non se distinguen os trazos da cara, coas mans dereitas sobre o peito e cuberta con simétrico manto. 


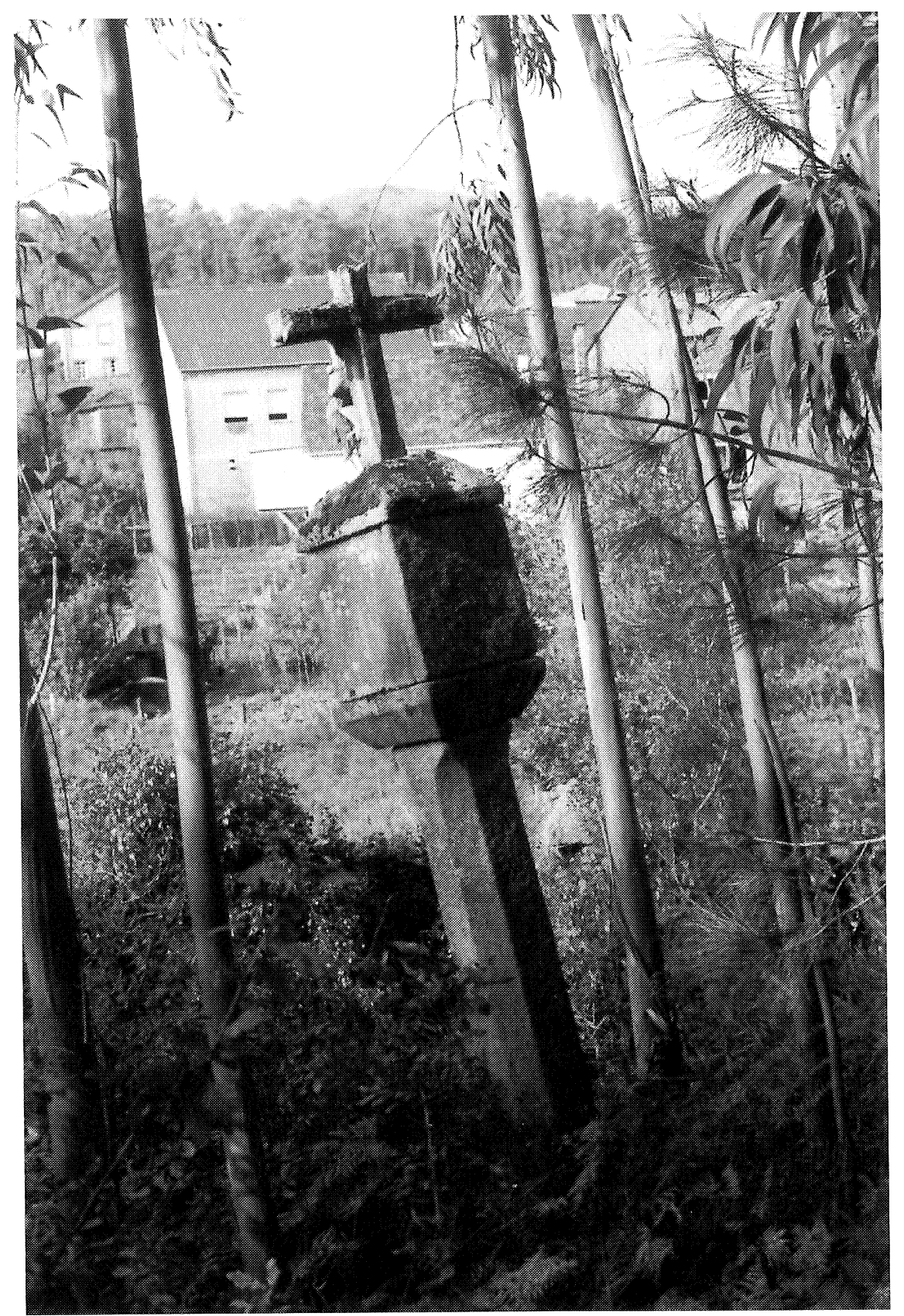

Ilustración XIII. Cruceiro Vello (A Vacariza). 
En tempos pasados, igual que todo o conxunto, esta figura estivo policromada. (Ilust. XIV).

A cruz está fincada no cumio do teito piramidal de catro lados. É de sección cadrada coas arestas rebaixadas menos non cabos, formando nos cantos unha flor tetrapétala co botón no medio. A imaxe de Cristo resulta moi hierática, colocada totalmente de fronte, cos trazos tanto da cara como do corpo en xeral pouco marcados. O pano de pureza teno atado á esquerda.

Mide dende o chan 4' 10 metros.

\section{Historia}

Non ten inscrición, polo que se descoñece a data en que foi ergueito. Segundo o inventario monumental de Rianxo elaborado polo concello, é de propiedade privada, atendendo a que está situado nun monte particular. Tendo en conta este feito, é de supoñer que debeu ser mandado labrar por algún antigo propietario do monte, aínda que tamén cabe a posibilidade de que el non fixese máis que cede-lo sitio, correndo cos gastos da obra outro veciño ou mesm toda a aldea.

Pode datar do século XVII, en particular contra os últimos anos.

Actualmente atópase abandonado no medio dun eucaliptal, con perigo de que se derrube, pois cada vez torce máis cara a corredoira, urxindo, polo mesmo, o seu traslado para preto das casas.

\section{Tradicións}

O sitio é axeitado para que haxa un cruceiro: lonxe da aldea, no medio do monte e nunha encrucillada do camiño sacramental. Esta foi durante séculos a vía seguida cos defuntos cara a igrexa parroquial. Quizais en tempos pasados contou con farol, que manterían aceso os veciños e os viandantes que pasaban por aquí cara a Rianxo ou para Padrón.

\section{PARROQUIA DE SANTA MARÍA DE LEIRO}

En total hai 16, nos que contamos as cruces, os cruceiros de varal e tamén os de capela. Destes últimos quedan catro, pero sabemos que houbo, ó menos, un máis, do que se descoñece o sitio onde estaba, non quedando actualmente del máis que o magnífico debuxo que nos deixou o polifacé- 


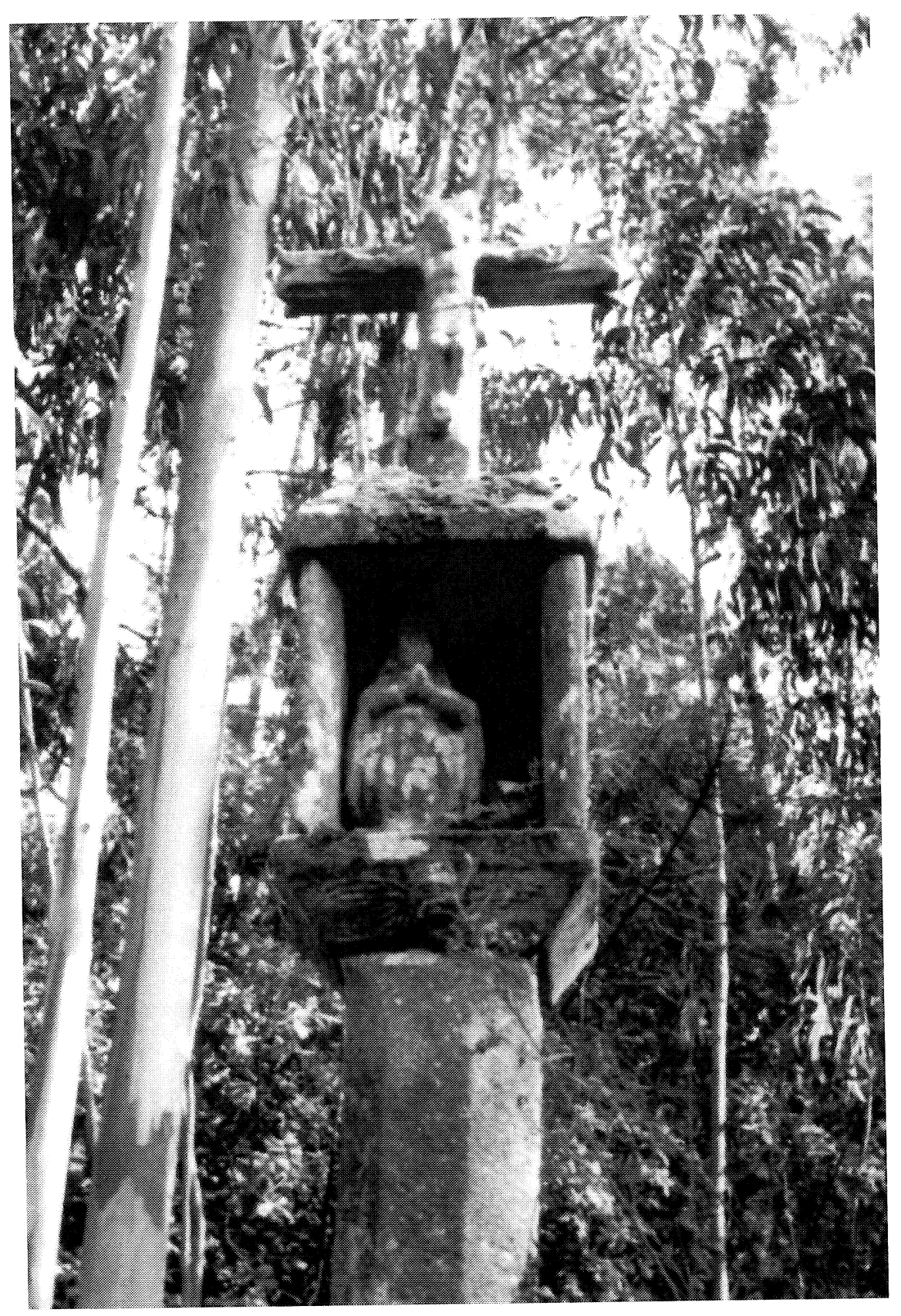

Ilustración XIV. Cruceiro Vello. Capela. 
tico artista rianxeiro, polo que decidimos darlle o seu nome: Cruceiro de Castelao.

\section{CRUCEIRO DA ALDEA}

\section{Situación}

No medio dunha encrucillada entre casas, na parte máis antiga da aldea de Brión. (Ilust. XV).

\section{Descrición}

O baseamento, de planta cuadrangular, consta de tres chanzos, afincándose no medio do superior o fuste, monolítico, de máis de 2'30 m de altura, sendo un dos máis esveltos dos existentes neste concello. Agás nos extremos, en que é de sección cadrada, o resto ten as arestas rebaixadas, con unha bola en cada comezo e unha cabeza en cada remate, moi rústicas. Estes mesmos motivos ornamentais repítense noutros cruceiros rianxeiros.

O capitel ou base sobre a que se asenta a fornela é de catro lados, adornado arredor por unha elegante moldura denticulada na parte inferior, unicamente alterada no fronte pola tradicional cabeza de querubín con ás. (Ilust. XVI).

A parte superior derrubouse hai moitos anos e non a volveron restaurar. Coidamos que xa non existise cando Castelao fixo o seu estudio sobre os cruceiros, pois o único que debuxou foi o da Fonte, situado a poucos metros de distancia, no mesmo lugar. Ultimamente puxéronlle enriba unha rústica imaxe, que coidamos represente a Virxe coas mans dereitas sobre o peito.

\section{Historia}

Non ten inscrición, pero a súa labra pódese situar entre 1636 (ano que figura no da Pastoriza, do mesmo estilo e coidamos tamén que santeiro ou taller), e 1667 (data que dá Castelao para o veciño da Fonte), é dicir, nas décadas centrais do século XVII. Estes tres cruceiros contan cos mesmos motivos ornamentais e tratados de igual xeito, polo que son atribuíbles ó mesmo santeiro ou a algún discípulo. 


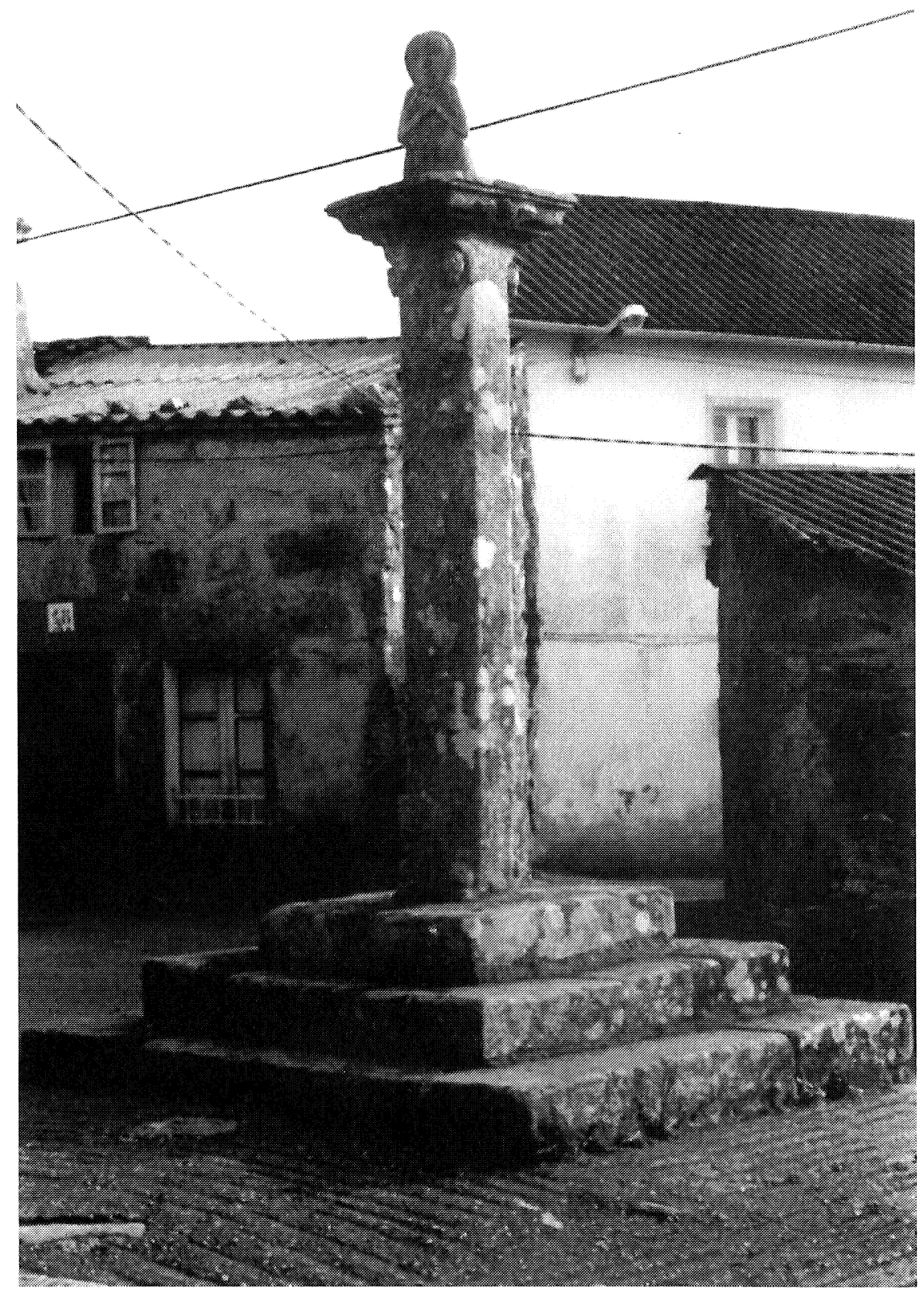

Ilustración XV. Cruceiro da Aldea (Brión). 


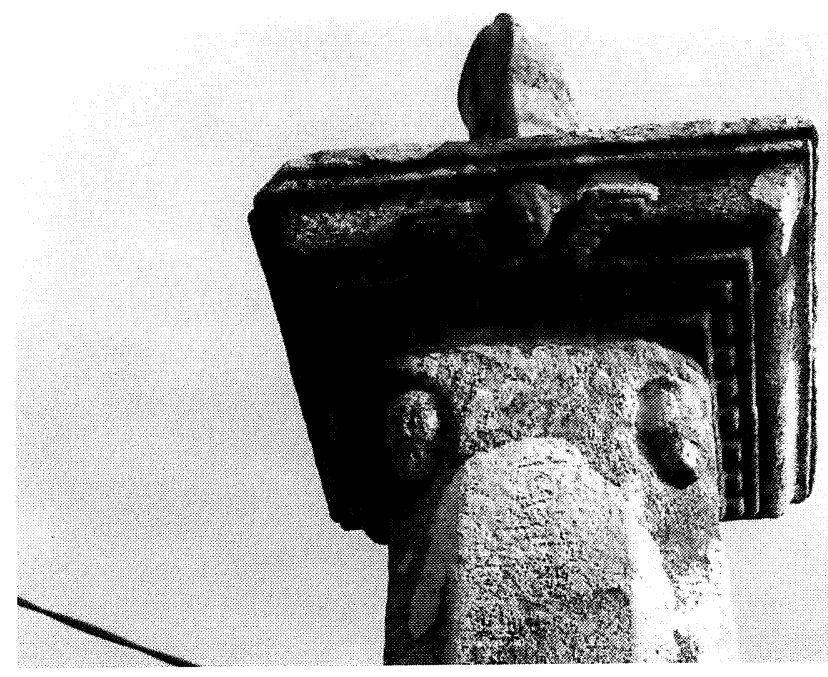

Ilustración XVI. Cruceiro da Aldea. Capitel.

\section{Tradicións}

A súa situación no medio dunha concorrida encrucillada, pola que tiñan que pasa-los máis dos veciños, amosa a importancia que debeu ter en tempos pasados, diante do que sempre estaría ardendo un farol de aceite. Non sabemos cando se derrubou, pero dende aquela ninguén se preocupou de recuperalo, de repoñerlle as pezas rotas ou perdidas, e que conste que foi unha mágoa, porque a obra merece ser restaurada, como se fixo hai algúns anos co da Pastoriza, na freguesía de Taragoña, con toda seguridade da mesma época e quizais tamén santeiro.

\section{CRUCEIRO DE CASTELAO}

\section{Situación}

Entre os de capela que publica Castelao no libro As cruces de pedra na Galiza (Buenos Aires, 1950), na última lámina -LXXIV-, reproduce tres cruceiros de capela situados no concello de Rianxo: o da Fonte de Brión, o do Souto do Outeiro e un da parroquia de Leiro.

Polo de agora esta é a única referencia que acadamos sobre este desaparecido cruceiro, non sabendo máis que se achaba en Leiro, pero sen

"CUADERNOS DE ESTUDIOS GALLEGOS", Tomo XLV, Fascículo 110, Santiago 1998. 
coñecer nin o nome que recibía, nin tampouco a aldea ou lugar onde estaba, nin se aínda conserva algún particular parte dos seus restos. Deica agora as nosas pescudas foron totalmente infructuosas, non aportando nada novo en ningún aspecto. Ante a carencia de datos, optamos por darlle o nome do artista rianxeiro.

\section{Descrición}

Tal vez aínda se conserven pezas soltas, pero, aínda que existan, descoñecémo-lo paradoiro. Polo de agora todo canto digamos verbo del, deducímolo do debuxo que Castelao fixo antes de 1936, época en que xa lle faltaba a cruz. (Ilust. XVII).

Supoñemos que tería baseamento con dous ou tres chanzos, afincándose no medio o fuste, formado -ó menos- por dúas pedras, de sección cadrada coas arestas chafranadas, a non ser nos remates, que nos superiores tiña en cada un unha cabeza. Nun destes rebaixes (o da dereita), había esculpida en relevo unha imaxe do apóstolo Santiago, cun libro na man esquerda e o caxato na outra. Os trazos da cara eran moi expresivos: con longo cabelo que lle caía simetricamente, abundante bigote e barba. Ficaba sobre unha pequena peaña semicircular que tiña por debaixo unha cuncha de vieira.

A pedra que fai de chan da capela ou capitel é cadrada, cos lados adornados con molduras, agás no frontal que tamén ten no medio unha cabeza de querubín con ás. Conta con cuberta piramidal, a catro augas. Da fornela só é de destacar que as xambas ou lousas laterais tiñan rebaixadas as arestas interiores para aumenta-la luz no interior. Dentro había unha imaxe da Virxe co Neno Xesús no colo, apoiado no lado esquerdo, mentres que coa man dereita parece que lle colle a tamén dereita do Fillo.

Xa daquela lle faltaba a cruz.

\section{Historia}

Aténdonos ó debuxo de Castelao e comparándoo con outros cruceiros, coidamos que date de entre 1636 (que é o ano que figura no da Pastoriza), e 1667 (que é o que dá Castelao para o da Fonte de Brión), tendo en conta certos trazos estilísticos comúns ós tres, que fan pensar nun mesmo artista ou discípulo.

Puido servir de modelo para o de Isorna, pois non só se repiten as caras nos remates dos rebaixes das arestas, senón que tamén ten un santo 


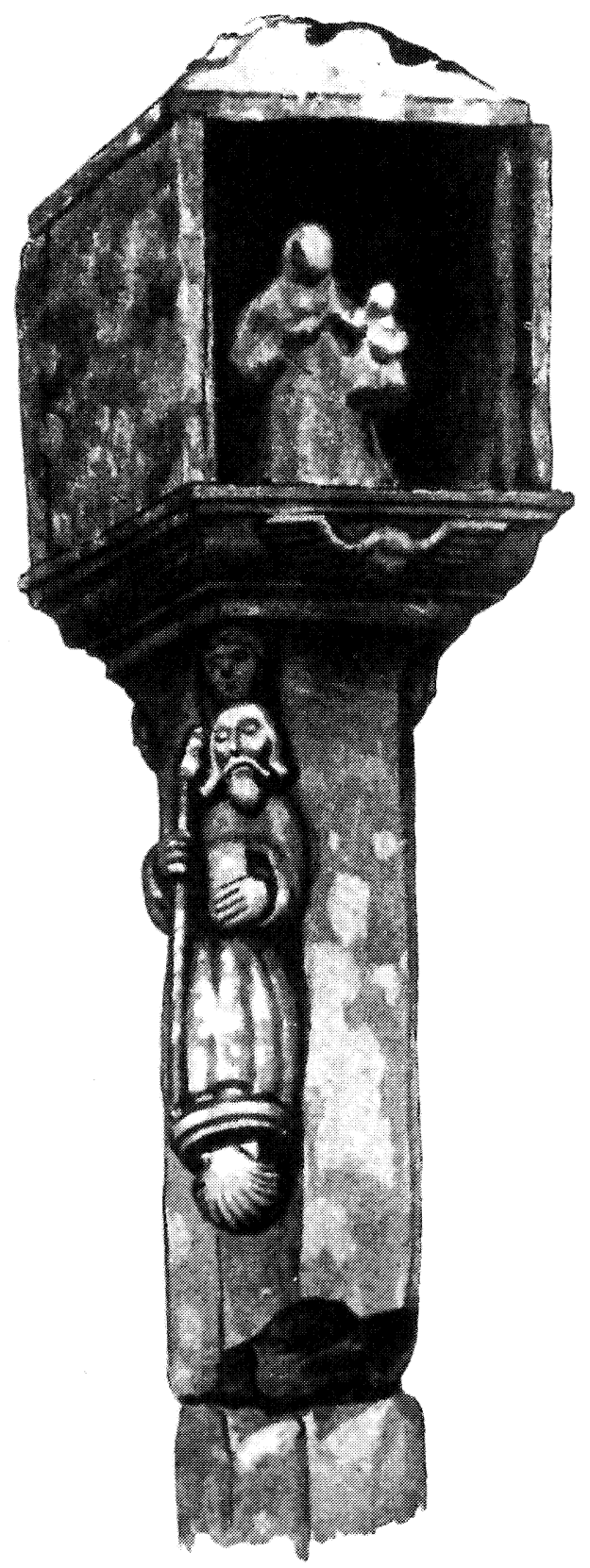

Ilustración XVII: Cruceiro de Castelao (Leiro). Debuxo de Castelao. 
gravado no fuste (que non é doado de identificar, pero que poidera corresponder ó mesmo apóstolo Santiago).

\section{Tradicións}

Coidamos que se erguería nunha encrucillada, pero non deixa de ser máis que unha hipótese, pois nada sabemos da súa localización.

\section{Continuará}

